\title{
A Geographical and Microbiological Assessment of Ganga Water in and Around Dakhshineswar Area, West Bengal
}

\author{
Jhulan Basu ${ }^{1}$, Sugata Datta ${ }^{2}$, Lopamudra Bagchi ${ }^{3}$ \\ ${ }^{1,2}$ (Microbiology Department, Dum Dum Motijheel College/West Bengal State University, India) \\ 3.(Geography Department, Dum Dum Motijheel College/West Bengal State University, India)
}

\begin{abstract}
Geographical and Microbiological study was done on river Ganga pollution in and around Dakhshineswar area and the magnitude of the pollution is being measured. River Ganga provides water to about $40 \%$ of population across the area and an extraordinary religious importance for Hindus. A large proportion of the sewage water with higher organic load in the Ganges is due to human waste, industrial waste and religious waste constantly being dumped in the river Ganga. A geographical analysis was done by questionnaire schedule for the study of people's perceptions, array and statistical analysis of the information was done. The river water samples were analyzed using standard laboratory procedure(MPN and Multiple tube Fermentation Technique) and it was found to contain a high percentage of disease causing species of Enterobacteriaceae (both fecal and non-fecal); leading to the belief Ganga water perhaps causes enteric diseases and waterborne infections. The $\mathrm{pH}$ of the water sample is 8.5 and the BOD was found to be greater than $5 \mathrm{mg} / \mathrm{ml}$ which have a negative impact on normal micro flora like Hilsha and Ganges River Dolphin which is listed as an endangered species. The coliform number remained fairly constant throughout the four months of sampling indicating a constant coliform index. Local people are quite dependent on Ganga emotionally, ritually and even for living their life which includes local population as well as the tourist and the devotees of Dakhshineswar temple. Among them Gangasnan has been one of the vividly offered traditional activity which always has been a cause of concern. Unfortunately ritualistic waste like food residuals, flowers, leaves, ashes, plastic carry bags, are also being dumped which further worsen the entire scenario. Therefore our primary objective should be to raise basic awareness among the populace about their regular activities associated with river Ganga.
\end{abstract}

Keywords: Coliform, Enterobacteriaceae, Sewage water, Water pollution,

\section{Introduction}

Ganga is not an ordinary river. It is a life line, a symbol of purity and virtue for countless people of India. From the Geographical viewpoint Ganga is main river of India. This perennial river originating from Himalaya and flows through many states before it confluence in the Bay of Bengal. Ganga water is considered to be pure and sacred even in the Caharaksanhita ancient medical journal. It has been believed from medieval times that Ganga water has no germs bacteria or fungi. But the condition has changed during past several decades. Nearly all the sewage industrial effluents, runoff from chemical fertilizer and pesticide used in agriculture within basin and large quantity of solid waste, including thousands of animals' carcasses and human crapes are now dumped in the river (Pardo et al.,1990; Boughriet et al., 1992; Yu et al.,2001; Klavins et al., 2000). In Bonn Declaration of Global water security 2013 the river Ganga was christen as one of the large polluted river in the world.

Water is one of the most precious natural and a key element in the socio-economic development of a country. However, rivers comprise the most important source of surface water. India is blessed with a large number of major, medium and small size rivers whose total catchment area is 252.8 million hectares. The Ganga basin is the largest river basin of Indian subcontinent. It covers over one -fourth of the country's total geographical area and it originate in the state of Uttarakhand. It is the home for about half of her population. The Ganga basin accounts for nearly 50 per cent of class 1 and class 2 towns of the country and the mode of discharge of the municipal waste is mainly into the river system. Thus water pollution may be defined as alteration in the physical, chemical and biological characteristics of water, which may cause harmful effects on human and aquatic life [1](D.R.Khullar,2006) and it faces several forced and unforced human activities .Water pollution is now a day's considered not only in terms of public health but also in terms of conservation, aesthetics and preservation of natural beauty and resources.

Main causes of water quality degradation:

- Urbanization

- Industries

- Agricultural runoff and improper agricultural practices

- Withdrawal of water 
- $\quad$ Religious and social practices

According to a report of National Water Quality Monitoring Programme 2011, organic matter and bacterial population of faecal origin continue to dominate the pollution problem in the river Ganga. The heavily polluted river is the major sources of municipal sewage, industrial waste, residues of chemical fertilizers which are dumped into water courses without any treatment unfit for drinking and even for bathing. Large scale pollution of river is turning into septic drains posing serious threat to the health of millions of people. In order to assess water quality of river Ganga, the Central Pollution Control Board has set up 57 water quality monitoring stations on the main stream of river Ganga, in association with State Pollution Control Boards of Uttarakhand, Uttar Pradesh, Bihar, Jharkhand and West Bengal.

\section{Materials and Methodology}

The Ganga water around Dakhshineswar area (Kamarhati Municipality, Ariadahaand Dakhshineswar) was chosen for the study. Kamarhati municipality for its administrative purpose has divided the area into 35 wards and a small portion of ward no.14 and $12\left(22^{\circ} 39^{\prime} 18^{\prime \prime} \mathrm{N}, 88^{0} 21^{\prime} 28^{\prime \prime} \mathrm{E}\right)$ has been selected for the sample survey(Fig 1).These wards were famous for existence of Dakhshineswar Kali Temple and Sarada Math ,Yogoda Math. The Kali temple is one of the most important religious spot of Hindu community. The selected area is about $10 \mathrm{~km}$ away from Dunlop area.

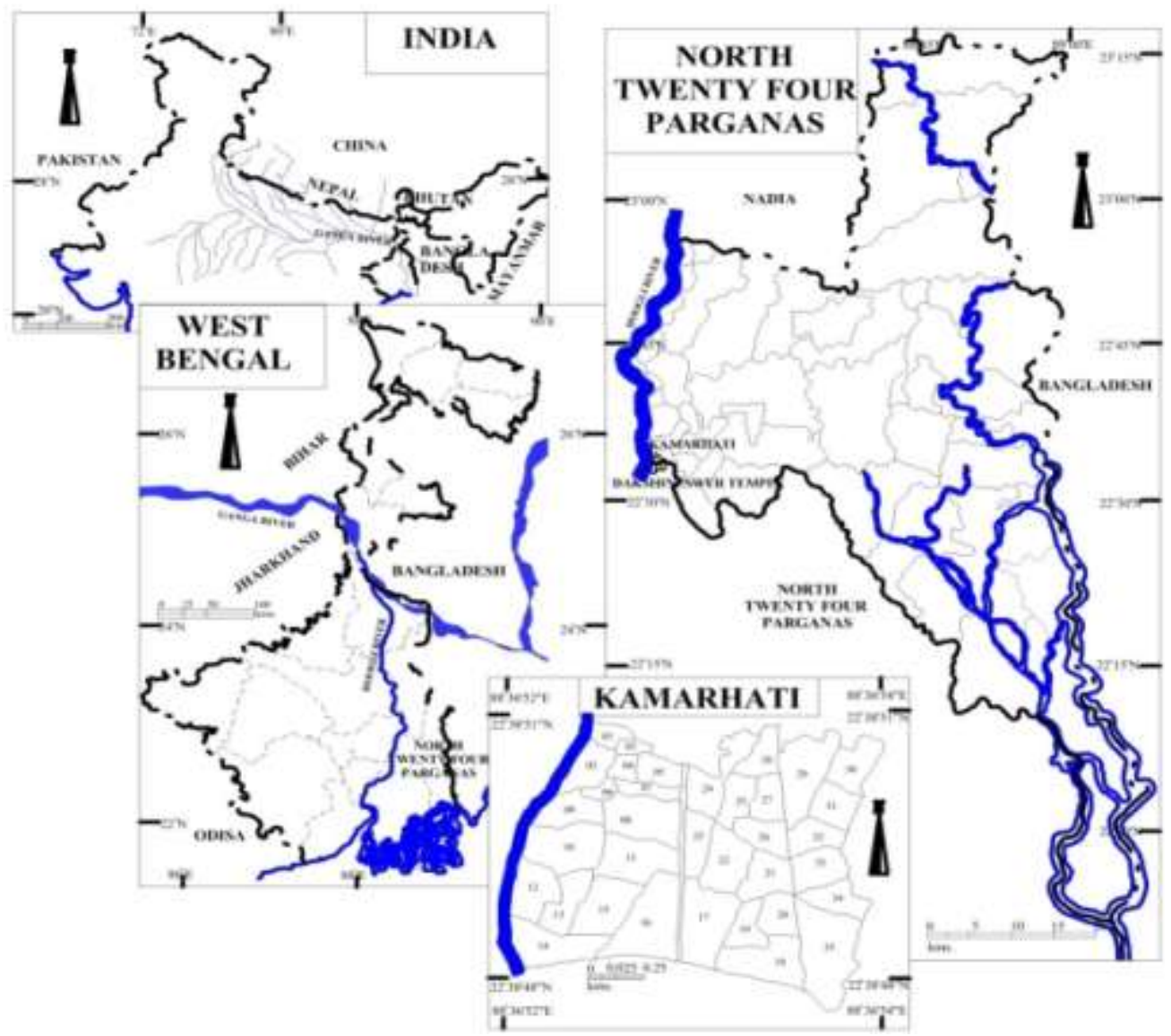

Fig 1: Location Map of River Ganga Dakhshineswar and Kamarhati Municipal area.

To satisfy the previously mentioned objectives the study has been divided into three consecutive phases- 1.Pre field phase, 2.Field phase, 3.Post field phase. Pre field phase constitute the preparation of base map and collection of informations available from secondary sources, i.e, from Kamarhati municipality, West Bengal Pollution Control Board and the electronic data from the internet. A questionnaire schedule for the study of people's perception i.e, to represent the views of different economic groups, sex and age groups with definite sample size was prepared. Fieldwork was conducted mainly for collection of primary data. The data was collected to get the view points of the victims as well as the beneficiaries of developmental works. A preliminary survey was conducted to identify the problems forced by local people relating to the use of Ganga water and Ganga pollution. Post field work involved: Array and Analysis of the information gathered, computation of primary and secondary data and their cartographic representation; interpretation of the maps and 
diagrams; recording various observations on temporal and spatial scale and analysis of the issues concerning Ganga pollution in the areas under study. The Ganga water sample was collected aseptically in the months of August, September, October and November 2015 in a mouthed sterilized glass containers and stored in ice boxes and brought to the laboratory for culturing immediately. BOD, DO, etc. were analyzed following the standard methods for the analysis of water and wastewater (APHA, 1992). Microbiological analysis of water was done by (1)Presumptive test,(2)Confirmed test (3) Completed test. Coliforms were enumerated using single and double strength lactose broths containing Durham's tube. 5 tube MPN test was carried out using the Ganga water.

\section{Results and Discussion}

The result of Geographical and Microbiological research are presented below.A primary survey was conducted to know the purposes they use Ganga water in the Fig 1.

\section{Purpose of use of Ganga water:}

Being a part of Hooghly industrial belt, this area is affected by the toxin pollutants discharged by the industries. The slum people near the river often use both washing and sanitation purpose which also cause river pollution. Religious activity like throwing flowers and ash of the burnt body creates pollution. A large number of domestic wastes are discharged in the river. Pilgrims take bath for their ritualistic purposes. Habits of discharging faecal wastes and urination in open spaces near Ganga shoreline makes the [2] Ganga faecal contamination even more complicated.[Fig 2]

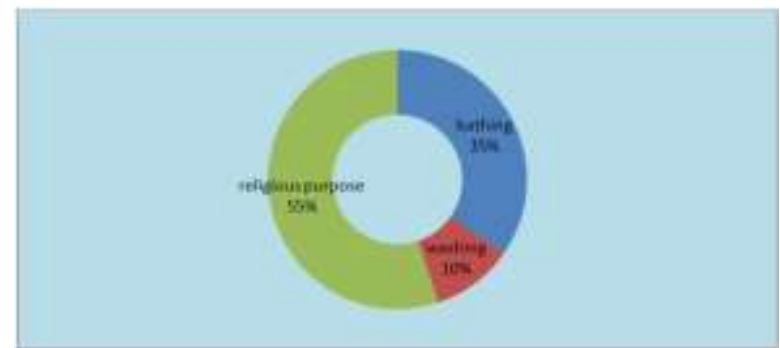

Fig 2: Purpose of use of Ganga water selected sampling location.

The people were asked if the water is good or not for using $42 \%$ of them said water quality is bad but $11 \%$ said it is good. Only $3 \%$ of them said the water quality is very bad.(Table 1)

Table 1: Water Quality of river Ganga according to the users in study area.

\begin{tabular}{|l|l|l|l|}
\hline Water Quality & Good & Bad & Very Bad \\
\hline \%of responds & 22 & 42 & 6 \\
\hline
\end{tabular}

\section{Status of Visible Traces of Fuel in Ganga:}

The water vessels are also responsible for water pollution at Dakhshineswar, Kamarhati and Ariadaha ferry ghats . The fuel emitted from the motorized vessels makes water polluted.(Fig 3). In maximum cases the fuel of the motorized vehicle is unrefined and parts of the motor parts are also customized old parts of other machine, cause leaking of oil spills on the river Ganga. The oil spill blackened the shoreline, threatening plankton, trees, and vast populations of small fishes and dolphins. According to the study local people observe less no of dolphin and it radices day by day. Not only the dolphin, inflow of Hilsha fish is also decreasing, they come to fresh Ganga water for laying eggs. They survey indicated that pilgrims, devotees and local people who use the Ganga water every day work have chance to develop gallbladder cancer, enteric disease and severe skin disease.

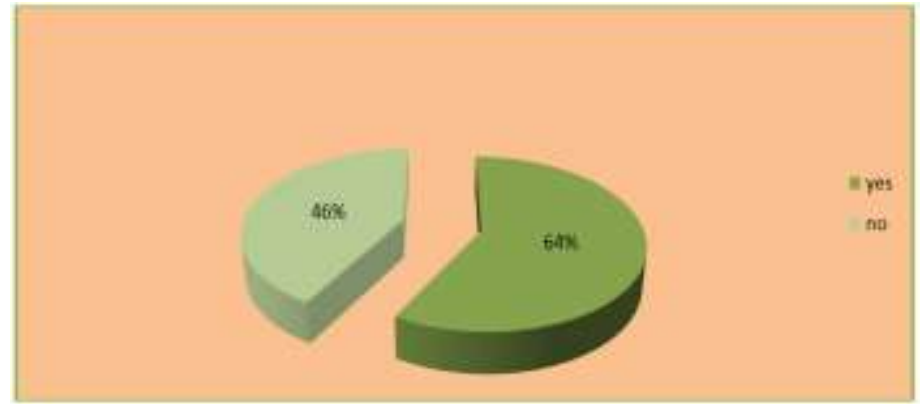

Fig 3: Status of visible traces of fuel in Ganga. 


\section{Sewage Pollution Load of Big Cities:}

According to a National Pollution Control Board's observations the situation is extremely vulnerable in Dakhshineswar area in West Bengal. Rivers have a self-cleansing ability, which allows for assimilation and treatment of biological waste by oxidation of anaerobic sludge digestion. But in the present context, selfcleaning in the river is much lower than the discharge of waste. [3] SunitaNarain mentioned the report of CPCB, where "2,723 million litre a day (MLD) of sewage is generated by 50 cities located along the river, which adds up to over 85 pr cent of the river's pollution Load". Municipal waste water discharge into Ganga from class I cities are 2561.7 million per day (MLD) and 1174.4 MLD waste water capacity exist. It is only $45.8 \%$ of the total discharge .It is almost same in our study area .The total amount of sewage generated in the study area and Kamarhati municipal area is 48.8MLD.(Table 2.)

Table 2: Sewage Pollution Load of Study Area

\begin{tabular}{|l|l|l|}
\hline Area & Total sewage(MLD) & Capacity of STP(MLD) \\
\hline Kamarhati & 48.8 & 8.8 \\
\hline Dakhineswar & 48.8 & 40 \\
\hline
\end{tabular}

\section{People's Perception on Necessary of Ganga Action Plan:}

Ganga Action Plan was first initiated by Prime Minister Rajiv Gandhi in 1986 with the main objective to improve the water quality by interception diversion and treatment of domestic sewage, present toxic and industrial waste identified grassy polluting units entering into the river.Till Feb 2014 Rs 939 crore had been spent on the Ganga Action Plan including 524 different schemes by Water Resources Minister Uma Bharaty. During this first phase of Ganga Action Plan total 462.04 core rupees was spent among which West Bengal got share as Rs 181.86 crore nearly $39.36 \%$ of the total money. The money was sanctioned for different projects like low cost sanitation, river front development, electric crematoria, sewage interception and diversion, sewage treatment plants and river traffic(Table 3). During second phase of Ganga Action Plan West Bengal got 1274 million rupees for various projects. Among them Baranagar, Kamarhati Municipality got 190.00 million rupees for building and running up the projects like sewage interception low cost sanitation, river front development, electric crematoria, and diversion, sewage treatment plants etc.(Table 5.)

Ganga Action Plan was initiated to check the increasing pollution in Ganga water. The main objective of the Gaga Action Plan (GAP) is to have an approach of integrated river basin management considering the various dynamic inter-actions between abiotic and biotic eco-system. In 1986 the Indian government had launched the first phase of the Ganga Action Plan (GAP-I) to protect the main Ganga basin at selected stretches along 25 cities in Uttar Pradesh, Bihar and West Bengal states. The government launched an expanded second phase (GAP-II) in 1993 to include four key tributaries - Damodar, Gomti, Mahanadi and Yamuna. But the plan could not fulfill its desired goal. The levels of coliform bacteria is over 2800 times more the level considered safe by the W.H.O (World Health Organisation). The local people of the study area asked about Ganga Action Plan. It is found that most of them hard about Ganga Action Plan (80\%). But still 20\% people never heard of it. (Fig 4.) The respondent were divided into three groups like dependent on Ganga, occasionally dependent and the rest of are nondependent. 64\% of respondent opined that another Ganga Action Plan is necessary to improve water quality of Ganga .(Table 3)and (Fig 4)

Table 3: People's perception on necessity of GangaAction Plan.

\begin{tabular}{|l|l|l|l|}
\hline People's Perception on GAP & Dependent on & Occationally & Not Dependent \\
\hline Necessary (64) & 48 & 12 & 4 \\
\hline Unnecessary(36) & 10 & 6 & 20 \\
\hline
\end{tabular}

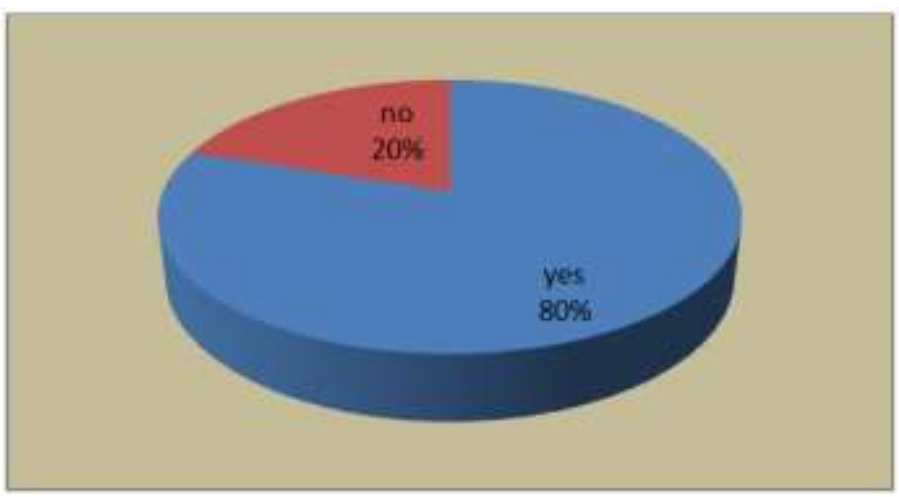

Fig 4: Aware of Ganga Action Plan in Study Area 
Table 4: Total sanctioned cost for Ganga action plan in West Bengal in(GAP-I)

\begin{tabular}{|l|l|}
\hline Name of the Schemes & No of scheme \\
\hline low cost sanitation & 22 \\
\hline river front development & 24 \\
\hline electric crematoria & 17 \\
\hline sewage interception and diversion & 31 \\
\hline sewage treatment plant & 15 \\
\hline Others & 1 \\
\hline
\end{tabular}

Table 5: Sanctioned and completion of different schemes GAP 1)

\begin{tabular}{|l|l|}
\hline Name of the schemes & Sanctioned \\
\hline interception and diversion & 88 \\
\hline low cost sanitation & 35 \\
\hline river front development & 43 \\
\hline sewage treatment plant & 28 \\
\hline electric crematoria & 35 \\
\hline
\end{tabular}

\section{Microbiological Analysis:}

The $\mathrm{pH}$ of the aquatic system is an important indicator of the water quality and the extent of the pollution in the area. A pH range of 6.5-8.5 is normally acceptable as per guidelines suggested by BIS (1991) and WHO (1993). The $\mathrm{pH}$ values obtained for the Ganga sites were 8.5. Anjum Praveen , Rajesh Kumar, Pratima and Rajat Kumar also reported nearly same pH in Ganga at Kanpur.[4]

BOD values indicate the extent of organic pollution in aquatic systems, which adversely affect the water quality. BOD values were found to be greater than $5 \mathrm{mg} / \mathrm{ml}$.These higher values are likely due to effluents discharged by industries. [5] Central Pollution Control Board (2009) also reported unsatisfied BOD due to $50 \%$ of untreated and partially treated sewage is dumped into the river.

The dissolved oxygen levels (DO) (Table no.6 ) in Ganga river indicate a sharp decline (DO limit $\leq 5.0$ O2/ liter). The low DO values may be attributed due to the high solid load and enormous untreated waste water discharge into the river indiscriminately round the year.

The results of microbiological research are presented in the following Table 6-11and Fig 5,6,7. The Ganga water tested showed a high number of coliforms and both fecal and non fecal coliforms were detected in the water sample. The challenge of pollution remains grim. According to[6] July 2013 estimates of the Central Pollution Control Board (CPCB), fecal coliform levels in the mainstream of the river some 2,500 km from Gangotri to Diamond Harbour remain above the acceptable level in all stretches, other than its upper reaches.

The number of coliforms ranged from 250 to 540 per $100 \mathrm{ml}$ of Ganga water sample an average of 373 coliforms per $100 \mathrm{ml}$. The coliform index more or less remained the same.[7] Bacterial contamination in the water of river Ganga was observed with over 370 coliform $/ 100 \mathrm{ml}$, the values extremely higher than recommended values of 1 coliform $/ \mathrm{ml}$. Most of these coliforms were of fecal type due to gravity discharges of faecal wastes from residents and animals from the nearby areas. According to [8] Sobey .M and [9] Kataria and Ambhore (2012) the presence of E.coli indicates potentially dangerous contamination requiring immediate attention.

Table6:Different parametric analysis River Ganga at study area in different months

\begin{tabular}{|l|l|l|l|l|l|}
\hline Ganga Water Samples & $\begin{array}{l}\text { Total solids } \\
(\mathrm{mg} / \mathrm{l})\end{array}$ & $\begin{array}{l}\text { Total dissolved solids } \\
(\mathrm{mg} / \mathrm{l})\end{array}$ & $\begin{array}{l}\text { Total suspended } \\
\text { solids (mg/l) }\end{array}$ & $\begin{array}{l}\text { Biological oxygen } \\
\text { Demand (mg/l) }\end{array}$ & $\begin{array}{l}\text { Dissolved } \\
\text { oxygen (mg/l) }\end{array}$ \\
\hline $\begin{array}{l}\text { Sample 1 (collected in } \\
\text { the month of August) }\end{array}$ & 295 & 223 & 30 & 6.67 & 2.83 \\
\hline $\begin{array}{l}\text { Sample 2 (collected in } \\
\text { the month of } \\
\text { September) }\end{array}$ & 329 & 294 & 35.3 & 7.53 & 3.63 \\
\hline $\begin{array}{l}\text { Sample 3 (collected in } \\
\text { the month of October) }\end{array}$ & 307 & 257 & 21 & 9.73 & 2.37 \\
\hline $\begin{array}{l}\text { Sample 4 (collected in } \\
\text { the month of } \\
\text { November) }\end{array}$ & 311 & 284 & 16.9 & 7.57 & 3.87 \\
\hline
\end{tabular}

Table 7: MPN Chart (Standard Methods for the Examination of Water and Wastewater, (1980); 15 ${ }^{\text {th }}$ ed, American Public Health Association, New York )[11]

\begin{tabular}{|l|l|l|}
\hline Ganga Water Samples & Combination of positives & Number of coliforms /100 ml Ganga water sample \\
\hline Sample 1 & $5-5-2$ & 540 \\
\hline Sample 2 & $5-4-4$ & 350 \\
\hline Sample 3 & $5-5-1$ & 350 \\
\hline Sample 4 & $5-3-5$ & 250 \\
\hline
\end{tabular}


Table 8: Presumptive test

\begin{tabular}{|l|l|l|l|l|}
\hline Test tubes & $\begin{array}{l}\text { Gas formation } \\
\text { for sample 1 }\end{array}$ & $\begin{array}{l}\text { Gas formation } \\
\text { for sample 2 }\end{array}$ & $\begin{array}{l}\text { Gas formation } \\
\text { for sample 3 }\end{array}$ & $\begin{array}{l}\text { Gas formation } \\
\text { for sample 4 }\end{array}$ \\
\hline $\begin{array}{l}\text { Control (double distilled } \\
\text { water) }\end{array}$ & Nil & Nil & Nil & Nil \\
\hline $\begin{array}{l}\text { Double Strength Lactose } \\
\text { broth+10ml Ganga water }\end{array}$ & $90 \%$ & $95 \%$ & $85 \%$ & $100 \%$ \\
\hline $\begin{array}{l}\text { Single strength Lactose } \\
\text { broth+0.1 ml of Ganga } \\
\text { water }\end{array}$ & $25 \%$ & $25 \%$ & $20 \%$ & $30 \%$ \\
\hline $\begin{array}{l}\text { Single strength Lactose } \\
\text { broth } \\
\text { water ml Ganga }\end{array}$ & $65 \%$ & $70 \%$ & $85 \%$ & $65 \%$ \\
\hline
\end{tabular}

Table 9: Confirmed test

Incubation time: 48 hours; Incubation time: $37^{\circ} \mathrm{C}$

\begin{tabular}{|l|l|l|}
\hline Ganga water Samples & EMB agar plate & Endo agar plate \\
\hline Sample 1 & $\begin{array}{l}\text { Small ,nucleated ,pink colonies with } \\
\text { golden metallic sheen were observed }\end{array}$ & $\begin{array}{l}\text { Small ,nucleated ,pink colonies with golden } \\
\text { metallic sheen were observed. }\end{array}$ \\
\hline Sample 2 & $\begin{array}{l}\text { Large ,translucent nucleated, pale } \\
\text { Colonies were observed. }\end{array}$ & $\begin{array}{l}\text { Small, nucleated, pink Colonies without golden } \\
\text { metallic sheen,opaque were observed. }\end{array}$ \\
\hline Sample 3 & $\begin{array}{l}\text { Small,discrete ,flat ,nucleated ,pink } \\
\text { colonies with dark centers with greenish } \\
\text { metallic sheen were observed. }\end{array}$ & $\begin{array}{l}\text { Small, nucleated ,pink colonies with golden } \\
\text { metallic sheen were observed. }\end{array}$ \\
\hline Sample 4 & $\begin{array}{l}\text { Small,discrete ,raised ,nucleated ,pink } \\
\text { colonies with dark centers with greenish } \\
\text { metallic sheen were observed. }\end{array}$ & $\begin{array}{l}\text { Small ,nucleated ,pink colonies with golden } \\
\text { metallic sheen were observed. }\end{array}$ \\
\hline
\end{tabular}

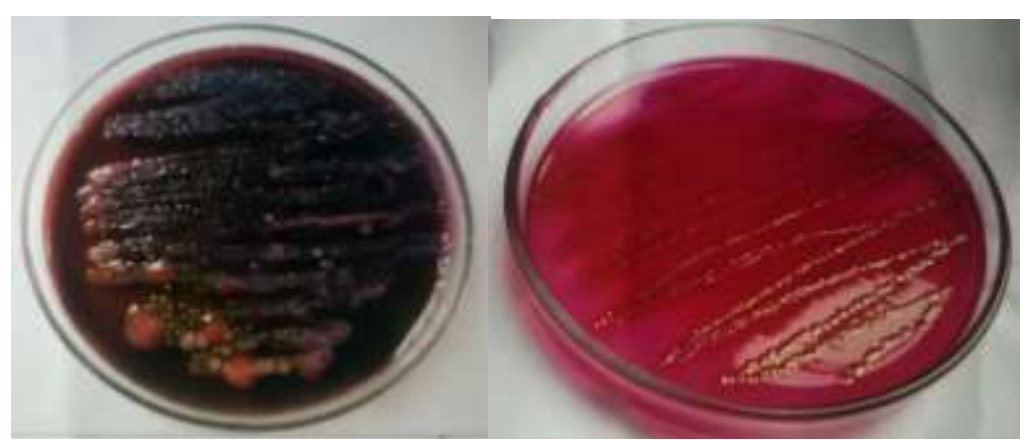

Fig 5: Colonies of nonfaecal and faecal coliform on EMB agar plate.

Table 10: Completed test

\begin{tabular}{|l|c|c|}
\hline Ganga Water Samples & ESSLB & DSSLB \\
\hline Sample 1 & + & + \\
\hline Sample 2 & + & + \\
\hline Sample 3 & + & + \\
\hline Sample 4 & + & + \\
\hline
\end{tabular}

Table 11: IMViC test

\begin{tabular}{|c|c|c|c|c|}
\hline Granga Water Samples & Indolit test & Netuyl rad tot & Vogereposinder tast & Curate tis \\
\hline Samplat & Regat layer cherry red & Rat olor observed & No apperance of red obour in $1 \mathrm{t}$. & No tribidity observed \\
\hline Sample? & A rellowish ring ottrical & The slution did net tim rad in wiors & 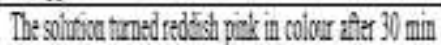 & Thishe gooth oowr \\
\hline Semple? & 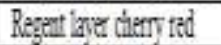 & Rad wior observed & So pperance of red whou in 1 if & Notricidity obsend \\
\hline Semplet & Regent laver ciern ted & Red clorer obserted & So zperarace of red colour in 1 in & Notribidity cberned \\
\hline
\end{tabular}



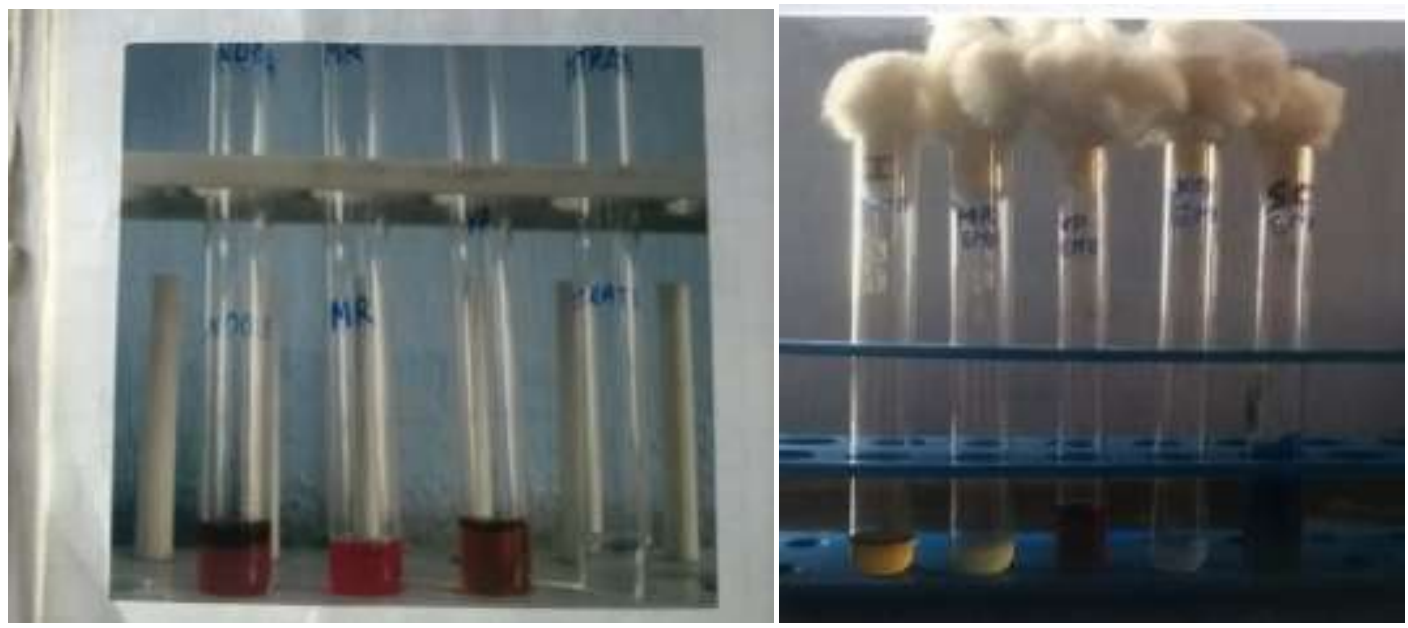

Fig 6: IMViC test for nonfaecal coliform.Fig 7:IMViC test for faecal coliform

\section{Conclusion}

The main focus of the study has been the pollution of river Ganga and the decreasing quality of water day by day. The main cause of this pollution is rapid urbanization and industrialization. Moreover lack of awareness also has been a genuine cause of concern. Human activities like bathing, washing, performing holy gestures in the river water are the other causes of water pollution.[10]According to Rakesh J Kejriwal , adverse impacts of GAP at Kanpur, the post treated sewage irrigation water being supplied to the farmland has led to widespread contamination of food chains, sharp decline in productivity of food crops, soil, vegetables, livestock and even milk; contamination of underground water meant for drinking purposes with attendant grave public health implications. The municipal waste disposal vats near the river also causing water pollution. Being a part of Hooghly industrial belt, this area is affected by the toxic pollutants discharged by the industries. More over people is not much aware of the actual condition of the river and they do not take any step towards the betterment of the river. Local authority is kind of failure in terms of taking action against the garbage throwing and waste water discharge in the river [11].Moreover, Z.Paluszak, A.Ligocka, B.Breza-Boruta explained that malfunctioning sewage treatment plant operation in river may poses a hazards to the normal biodiversity of the environment. So sewage treatment plant should monitor to determine the efficacy of technology to reduce microbiological threats .Many people even think that Ganga cannot be polluted and this holy river is as sacred as it was in years back. According to local people the Ganga action plan were not fruitful at all. Though Baranagar Kamarhati sewage treatment plant was established but its capacity hasn't been up to the mark. Once again higher level of coliforms are present in almost every part of Ganga but Ganga action plan has not been adequately address the issue of coliforms.

\section{References}

[1] D.R. Khullar, India: A Comprehensive Geography (Kaiyani Publishers, Ludhiana)Second (Ed2006) Water Pollution,page 289-300

[2] REASONER D.J Microbiology detection of bacterial pathogens and their occurrence J.WPCF.54(6)946.1982 .

[3] SUNITA Narain Ganga The River Its Pollution And What We Can Do To Clean It, Centre for Science and Environment briefing paper.

[4] ANJUM PRAVEEN , Rajesh Kumar, Pratima And Rajat Kumar. Physio- Chemical Properties of the Water of River Ganga at Kanpur, International Journal of Computational Engineering Research\|Vol, 03\|Issue, 4\|

[5] Central Pollution Control Board (2009) Ganga water quality trend .

[6] CENTRAL POLLUTION CONTROL BOARD Ministry of Environment and Forests, Govt. of India) PariveshBhawan, East Arjun Nagar, Delhi - 110032 Website: www.cpcb.nic.in, JULY, 2013.

[7] R.Sugmar and B.Anandharaj,Assessment of Bacterial Load in the Fresh water Lake System of Tamil Nadu.International Journal of Current Microbiology and Applied Sciences. 2016 5(6):236-246.

[8] SOBSEY M. Inactivation of Health Related Microorganisms I water by disinfection process.Wat.Sei.Tech 21 (3).179.1989.

[9] KATARIA.H.C.Ambhore.S.2012.Pre-and .post-monsoon physic-chemical assessment of drinking water quality of Gandinagar Area of Bhopal.Current World Environment,7(2):309-311

[10] KRISHNA MURTI, C.R., Bilgrami, K.S., Das. T.M. and Mathur, R.P., "The Ganga A Scientific Study", Northern Book Depot, New Delhi, 1991.

[11] Rakesh J Kejriwal, CRITICAL ANALYSIS OF GAP, May 28, 2007, http://www.ecofriends.org/main/eganga/images/Critical\%20analysis\%20of\%20GAP.pdf

[12] Standard Methods for the Examination of Water and Wastewater, (1980); $15^{\text {th }}$ ed, American Public Health Association, New York

[13] Z.Paluszak, A.Ligocka, B.Breza-Boruta: Effectiveness of Sewage Treatment Based on Selected faecal Bacteria Elimination in Municipal Wasetewater Treatment in Torun',Polish journal of Environmental Studies Vol 12 No.3 (2003),345-349. 